\title{
Hyperproinsulinemia Is Associated with Increased $\beta$ Cell Demand after Hemipancreatectomy in Humans
}

\author{
Elizabeth R. Seaquist, ${ }^{\star}$ Steven E. Kahn, ${ }^{\ddagger}$ Penny M. Clark, ${ }^{\S}$ C. Nicholas Hales, ${ }^{\S}$ Daniel Porte, Jr., ${ }^{\ddagger}$ and R. Paul Robertson ${ }^{\star}$ \\ *Division of Diabetes, Endocrinology, and Metabolism, Department of Medicine, University of Minnesota, Minneapolis, \\ Minnesota 55455; ${ }^{\ddagger}$ Division of Metabolism, Endocrinology, and Nutrition, Department of Medicine, University of Washington and the \\ Veterans Affairs Medical Center, Seattle, Washington 98108; and ${ }^{\S}$ Department of Clinical Biochemistry, Addenbrooke’s Hospital, \\ CB2 2QR Cambridge, United Kingdom
}

\begin{abstract}
The cause of disproportionate hyperproinsulinemia in patients with type II diabetes is controversial. To examine whether increased $\beta$ cell demand might contribute, we measured proinsulin and insulin concentrations in clinically healthy humans who had undergone hemipancreatectomy for the purpose of organ donation, a procedure previously demonstrated to increase $\beta$ cell demand and diminish insulin secretory reserve capacity. Subjects were studied at least $1 \mathrm{yr}$ after hemipancreatectomy. Seven donors were followed prospectively and served as their own controls. Nine additional donors were matched with normal controls (crosssectional group). Fasting serum concentrations of intact proinsulin and conversion intermediates (total) were measured by a two-step radioimmunoassay; independent determinations of intact proinsulin and 32,33 split proinsulin were performed using an immunoradiometric assay. Serum total proinsulin values were significantly greater in hemipancreatectomized groups than controls (prospective group: predonation $=6.24 \pm 1.14 \mathrm{pM}$, postdonation $=34.63 \pm 17.47 \mathrm{pM}$, $P<0.005$; cross-sectional group: controls $=5.78 \pm 1.12 \mathrm{pM}$, donors $=15.22 \pm 5.20 \mathrm{pM}, P<0.025)$. The ratio of total proinsulin to immunoreactive insulin was directly correlated with fasting plasma glucose and showed a significant inverse relationship to secretory reserve capacity. Both absolute and relative hyperproinsulinemia is found in hemipancreatectomized donors. These data demonstrate that partial pancreatectomy with its associated increase in $\beta$ cell demand raises measures of proinsulin in humans. (J. Clin. Invest. 1996. 97:455-460.) Key words: proinsulin • insulin • hemipancreatectomy $\bullet$ diabetes $\bullet$ pancreas transplantation
\end{abstract}

\section{Introduction}

Hyperproinsulinemia may be either absolute, relative, or both. In simple obesity, there is a proportionate increase in proinsu-

Preliminary reports of these data were presented at the meeting of the Western Section of the American Federation of Clinical Research, 10-12 February 1994, and at the national meeting of The American Diabetes Association, 11-14 June 1994.

Address correspondence to Elizabeth R. Seaquist, M.D., University of Minnesota, Box 101, 420 Delaware St., S.E., Minneapolis, MN 55455. Phone: 612-626-4833; FAX: 612-626-3133; E-mail: sequ001@ maroon.tc.umn.edu.

Received for publication 9 August 1995 and accepted in revised form 12 October 1995.

The Journal of Clinical Investigation

Volume 97, Number 2, January 1996, 455-460 lin, and, therefore, only absolute hyperproinsulinemia is present (1). In type II diabetes with fasting hyperglycemia, there is a disproportionate hyperproinsulinemia relative to insulinemia even in lean type II patients without absolute hyperinsulinemia or hyperproinsulinemia (2). Disproportionate hyperproinsulinemia has also been found in women with a history of gestational diabetes (3) and in the first-degree relatives of patients with type I diabetes (4-7), and it predicts the transition from impaired glucose tolerance to non-insulindependent diabetes mellitus in Japanese Americans (8). Because each of these groups has diabetes or is at risk for the development of the disease, disproportionate hyperproinsulinemia has been advanced as an early marker for $\beta$ cell dysfunction (9). However, the cause of this relative hyperproinsulinemia is unknown. Some investigators believe it arises from increased demand on the pancreatic $\beta$ cell and is the result of premature release of immature insulin secretory granules (10), whereas others suggest it occurs as a result of a defect in proinsulin processing in the $\beta$ cell (9). To investigate the causes of this type of hyperproinsulinemia, we asked whether disproportionate hyperproinsulinemia develops in clinically healthy humans undergoing hemipancreatectomy for the purpose of organ donation. Because human pancreas donors have reduced glucose- and arginine-induced insulin secretion and decreased maximum $\beta$ cell secretory reserve capacity, as measured by glucose potentiation of arginine-induced insulin secretion (11), they experience increased secretory demand on their $\beta$ cells after hemipancreatectomy. In this study we hypothesized that enhanced demand would increase serum proinsulin levels disproportionately after hemipancreatectomy.

\section{Methods}

Subject recruitment. Subjects were recruited from the University of Minnesota registry of hemipancreatectomized organ donors who had given half their pancreas to a diabetic family member with type I diabetes mellitus. The selection criteria for these subjects has previously been described $(12,13)$. In brief, all were in good health and had normal fasting glucose and insulin values, normal oral glucose tolerance tests, and normal insulin-secretory responses to glucose before surgery. Subjects were required to be $10 \mathrm{yr}$ older than the age at which the proposed recipient developed diabetes mellitus. In all cases, transplantation was at least $10 \mathrm{yr}$ after diabetes onset in the recipient. The majority of donors included in this investigation was found to have HLA haplotypes positive for DR3 and/or DR4, and all have participated in a larger ongoing study chronicling the metabolic effects of hemipancreatectomy on healthy humans $(11,13,14)$. Two groups of donors were selected for this study. The first, termed the prospective group, was chosen because of the availability of fasting serum samples obtained both before and after hemipancreatectomy. In the second donor group, termed the cross-sectional group, only postoperative serum samples were available for study. They were se- 
lected based on the availability of fasting serum samples obtained from matched control subjects at the same approximate point in time. Control subjects were originally recruited into the study by advertisement and were matched to the donors with respect to age and body mass index. No control subject had a first-degree family member with type I diabetes mellitus. The Committee on the Use of Humans in Research at the University of Minnesota approved this investigation.

Metabolic tests. Arterialized blood samples were obtained for glucose, insulin, and proinsulin determinations in the morning after an overnight fast. Plasma was separated from blood for glucose determinations within $10 \mathrm{~min}$ of acquisition. Serum samples for hormones were allowed to clot for $30 \mathrm{~min}$ after collection and were stored at $-20^{\circ} \mathrm{C}$ until assayed. Oral glucose tolerance tests were performed in donors before and after surgery as previously described (13). $\beta$ cell reserve function was assessed by the method of glucose potentiation $(15,16)$ as modified by Seaquist and Robertson (11), by which the maximal acute insulin response to an intravenous bolus of arginine $\left(\mathrm{AIR}_{\max }\right)^{1}$ is determined after infusing sufficient glucose (as $20 \%$ dextrose in water) to achieve a serum glucose concentration $\geq 27 \mathrm{mM}$.

Assays. Glucose values were measured by an Autoanalyzer (Beckman Instruments, Inc., Fullerton, CA). Serum immunoreactive insulin (IRI) was determined by a modification of the double-antibody method of Morgan and Lazarow (17). In this assay, the insulin antibody detects proinsulin and its conversion intermediates on an equimolar basis with insulin. Thus, IRI measurements reflect the total amount of insulin, intact proinsulin, and proinsulin conversion intermediates present in the specimen. The intra- and interassay coefficients of variation (CVs) of this assay are 8 and $12 \%$, respectively. Intact proinsulin and proinsulin conversion intermediates were determined by previously described methods (18), whereby serum is first immunoprecipitated with an antibody directed against C-peptide, and quantitation is then obtained by radioimmunoassay of the resuspended pellet using an antibody directed against insulin. This assay has intra- and interassay CV values of 10 and $14 \%$, respectively. Since the antibody used in this assay does not discriminate between intact proinsulin and its conversion intermediates, they are all included in the "proinsulin" measured in this assay. To determine whether hemipancreatectomy alters the normal sequential processing of proinsulin (19), samples from six of the prospectively studied donors were also assayed for 32,33 split proinsulin, proinsulin, and insulin using a two-site immunoradiometric assay. This assay has intraand interassay CVs of $<10$ and $<15 \%$, respectively (20). The concentration of 32,33 split proinsulin intermediates detected by this assay includes des-31,32, and 32,33 split proinsulin (19). Serum concentrations of islet cell antibodies were kindly determined by Dr. Noel Maclaren using an indirect immunofluorescent assay previously described (21).

1. Abbreviations used in this paper: $\mathrm{AIR}_{\max }$, maximal acute insulin response; $\mathrm{CV}$, coefficient of variation; IRI, immunoreactive insulin.
Data analysis. Data are presented as mean \pm SEM. The proportion of proinsulin that comprised IRI (PI/IRI) was calculated as PI/ IRI $\times 100$ and is expressed as a percentage. The ratio of proinsulin secreted to true insulin secreted was calculated as PI/(IRI - PI). $\mathrm{AIR}_{\text {max }}$ is the mean of the peak three insulin values measured within $5 \mathrm{~min}$ after the administration of arginine at serum glucose $\geq 27 \mathrm{mM}$, with the prestimulus insulin value subtracted. Differences between groups were determined by nonparametric analysis. A $P$ value $<0.05$ was considered statistically significant.

\section{Results}

Seven hemipancreatectomized human donors were studied both before and after organ donation (Table I). These subjects were studied $18 \pm 5$ mo after surgery. Fasting glucose values were elevated on follow-up in each of the donors as compared with their predonation value, and three subjects demonstrated a diabetic response to an oral glucose tolerance test at the time of the postdonation exam (Table II). None of these subjects were receiving treatment for diabetes at the time of study. All five donors studied prospectively by the potentiation protocol demonstrated a decrease in their $\mathrm{AIR}_{\max }$ after hemipancreatectomy. None of these subjects had detectable serum concentrations of islet cell antibodies at the time of their postdonation study.

Nine additional donors were matched to nine control subjects with respect to age and body mass index (Table I). These subjects were studied $60 \pm 8$ mo after surgery and had higher fasting glucoses than did their controls $(P<0.05)$. Two of these donor subjects were found to have a diabetic response to an oral glucose tolerance test at the time of the follow-up investigation, but none were receiving treatment for diabetes at the time of study (Table II). Donors had a significantly lower $\mathrm{AIR}_{\max }$ than did controls $(P<0.001)$. Donors did not have detectable serum concentrations of islet cell antibodies at the time of study.

Proinsulin values were significantly higher in both donor groups after hemipancreatectomy as compared with their respective controls (Figs. 1 and 2). In those subjects studied prospectively, proinsulin increased from $6.24 \pm 1.14$ pM before donation to $34.63 \pm 17.47 \mathrm{pM}$ after donation $(P<0.05)$. In the cross-sectionally studied group, donors had a proinsulin concentration of $15.22 \pm 5.20 \mathrm{pM}$, and controls had a value of $5.78 \pm 1.12 \mathrm{pM}(P<0.025)$. Interestingly, the mean proinsulin value measured in donors before undergoing hemipancreatectomy was not different from that measured in normal controls $(6.24 \pm 1.14 \mathrm{pM}$ vs $5.78 \pm 1.12 \mathrm{pM}, P=\mathrm{NS})$.

IRI was the same in donor groups and their respective con-

Table I. Subject Characteristics

\begin{tabular}{|c|c|c|c|c|c|c|}
\hline & Gender & Age & Body mass index & Fasting glucose & $\operatorname{Air}_{\max }$ & Mo since donation \\
\hline & $M / F$ & $y r$ & $\mathrm{~kg} / \mathrm{m}^{2}$ & $m M$ & $p M$ & \\
\hline \multicolumn{7}{|l|}{ Prospective data } \\
\hline Predonation & $3 / 4$ & $31 \pm 2$ & $25.8 \pm 2.1$ & $4.5 \pm 0.1$ & $2,580 \pm 444$ & - \\
\hline Postdonation & $3 / 4$ & $33 \pm 2$ & $25.6 \pm 2.1$ & $6.3 \pm 0.7 *$ & $780 \pm 276^{*}$ & $18 \pm 5$ \\
\hline \multicolumn{7}{|c|}{ Cross-sectional data } \\
\hline Controls & $4 / 5$ & $38 \pm 3$ & $23.8 \pm 1.1$ & $4.9 \pm 0.2$ & $1,632 \pm 210$ & - \\
\hline Donors & $3 / 6$ & $38 \pm 3$ & $23.8 \pm 1.0$ & $5.4 \pm 0.1^{\ddagger}$ & $714 \pm 90 *$ & $60 \pm 8$ \\
\hline
\end{tabular}

$* P \leq 0.005 ;{ }^{*} P<0.05$. 


\begin{tabular}{|c|c|c|c|c|c|c|c|c|c|c|c|c|}
\hline \multirow[b]{3}{*}{ Donor } & \multirow[b]{3}{*}{$\mathrm{Hgb} \mathrm{A} 1 \mathrm{C} \%$} & \multicolumn{11}{|c|}{ Glucose OGTT time (min) } \\
\hline & & -10 & -5 & 15 & 30 & 60 & 90 & 120 & 150 & 180 & 240 & 300 \\
\hline & & \multicolumn{11}{|c|}{ Serum glucose concentration $(\mathrm{mg} / \mathrm{dl})$} \\
\hline \multicolumn{13}{|c|}{ Prospective data } \\
\hline 1 & 4.8 & 92 & 88 & 151 & 176 & 166 & 162 & 196 & 108 & 119 & 86 & 63 \\
\hline 2 & 5.2 & 95 & 87 & 106 & 146 & 137 & & 105 & 112 & 112 & 85 & 84 \\
\hline 3 & 8.3 & 163 & 160 & 201 & 239 & 303 & 342 & 375 & 364 & 356 & 252 & 193 \\
\hline 4 & 4.8 & 100 & 98 & 127 & 197 & 213 & 186 & 166 & 135 & 136 & 110 & 59 \\
\hline 5 & 5.6 & 107 & 109 & 160 & 179 & 164 & 242 & 265 & 294 & 285 & 225 & 145 \\
\hline 6 & 7.5 & 222 & 218 & 260 & 277 & 360 & 382 & 419 & 397 & 382 & 291 & 244 \\
\hline 7 & N/A & 100 & 98 & 145 & 189 & 141 & 138 & 134 & 90 & 78 & 86 & 91 \\
\hline Mean & 6.0 & 126 & 123 & 164 & 200 & 212 & 242 & 237 & 214 & 210 & 162 & 126 \\
\hline SEM & 0.6 & 19 & 18 & 19 & 17 & 33 & 41 & 46 & 50 & 48 & 34 & 27 \\
\hline \multicolumn{13}{|c|}{ Cross-sectional data } \\
\hline 8 & 5.4 & 97.0 & 97 & 132 & 163 & 136 & 145 & 124 & 111 & 100 & 65 & 59 \\
\hline 9 & 5.5 & 95 & 96 & 128 & 171 & 225 & 265 & 224 & 188 & & 129 & 82 \\
\hline 10 & 5.7 & 102 & 102 & 135 & 180 & 164 & 154 & 153 & 95 & 69 & 57 & 79 \\
\hline 11 & 5.7 & 98 & 99 & 148 & 197 & 224 & 189 & 145 & 110 & 94 & 65 & \\
\hline 12 & 5.1 & 144 & 140 & 209 & 261 & 222 & 282 & 292 & 368 & 344 & 273 & 191 \\
\hline 13 & 4.9 & Not done & & & & & & & & & & \\
\hline 14 & 5.2 & 98 & 103 & 103 & 126 & 118 & 125 & 155 & 170 & 136 & 156 & 128 \\
\hline 15 & 5.0 & 103 & 103 & 156 & 177 & 199 & 214 & 150 & 211 & 150 & 86 & 74 \\
\hline 16 & 4.8 & Not done & & & & & & & & & & \\
\hline Mean & 5.3 & 105 & 106 & 144 & 182 & 184 & 196 & 178 & 179 & 149 & 119 & 102 \\
\hline SEM & 0.1 & 7 & 6 & 12 & 16 & 17 & 23 & 22 & 36 & 41 & 29 & 20 \\
\hline
\end{tabular}
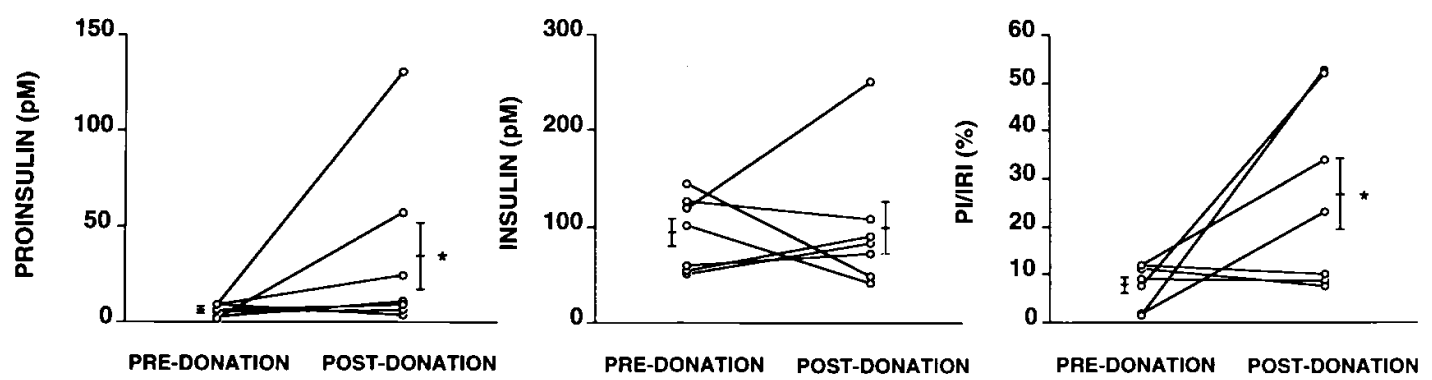

Figure 1. Measures of proinsulin and IRI before and after hemipancreatectomy. Seven donors were studied prospectively before and after hemipancreatectomy. Absolute serum concentrations of proinsulin and the ratio of proinsulin to IRI were significantly higher after hemipancreatectomy $(* P<0.05)$, whereas IRI values were unchanged after hemipancreatectomy.
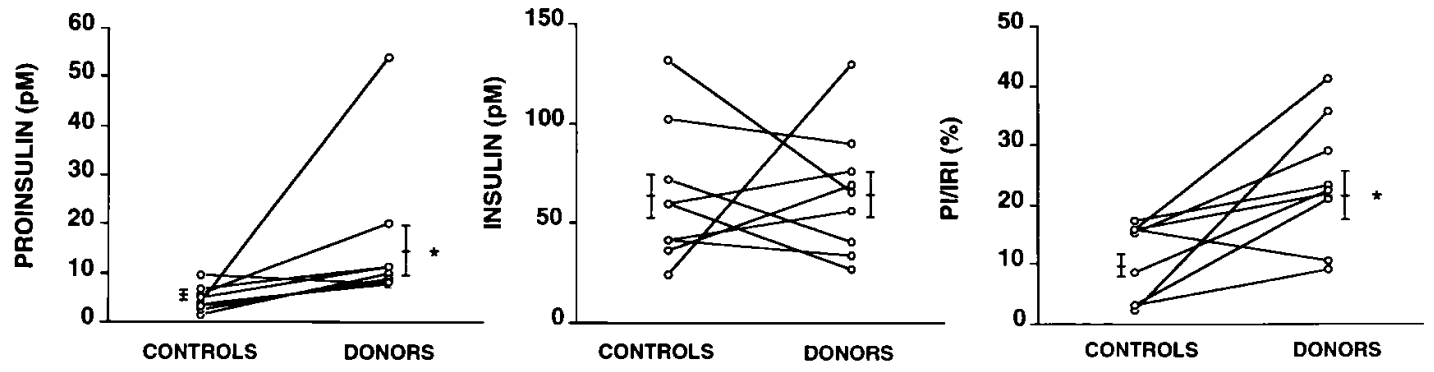

Figure 2. Measures of total proinsulin and IRI in donors and controls. Nine donors were compared with controls matched for age and body mass index. Serum proinsulin concentrations and the ratio of proinsulin to IRI were significantly higher in donors than in controls $(* P<0.05)$, whereas the IRI concentrations were unchanged. 


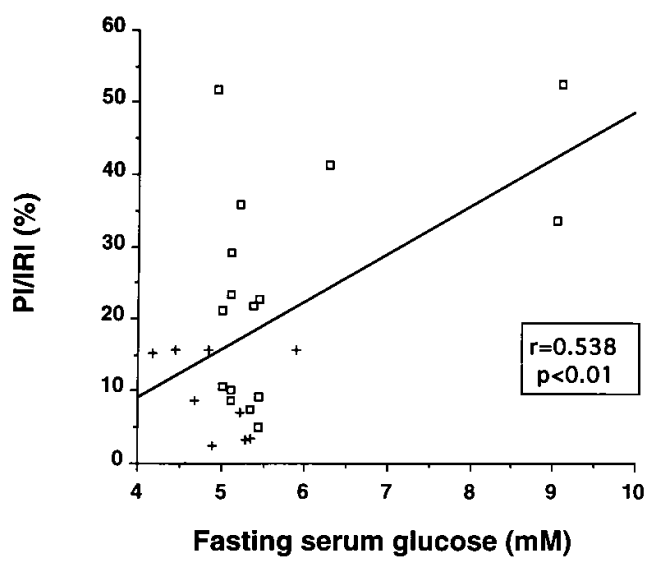

Figure 3. The ratio of total proinsulin to IRI correlates with fasting glucose concentrations. The ratio of total proinsulin to IRI increased as a function of fasting glucose concentration in donor $(\square)$ and control groups $(+)$.

trols (Figs. 1 and 2). The proportion of IRI comprised of proinsulin (PI/IRI) was found to be significantly higher in both donor groups when compared with their respective controls (Figs. 1 and 2). This proportion increased from $7.8 \pm 1.7 \%$ preoperatively to $26.9 \pm 7.5 \%$ postoperatively in those donors studied prospectively $(P=0.05)$. Controls in the cross-sectionally studied group had a proportion of $9.7 \pm 2.0 \%$, as compared with a value of $21.9 \pm 4.1 \%$ in donors $(P=0.01)$. When the ratio of circulating proinsulin to true insulin is compared, hemipancreatectomized donors also had higher values than did their controls, although statistical significance was achieved only in the cross-sectionally examined group. This ratio in donors before surgery was $0.09 \pm 0.02$, as compared with $0.47 \pm$ 0.17 after donation $(P=\mathrm{NS})$. The ratio in cross-sectionally studied donors was $0.31 \pm 0.07$, as compared with $0.11 \pm 0.02$ in their controls $(P=0.01)$.

A positive significant correlation was found between the PI/IRI and fasting glucose $(r=0.54, P<0.01$, Fig. 3). A similar relationship was also found between the PI/IRI and AIR $_{\max }$ $(r=0.62,<0.01$, Fig. 4$)$.

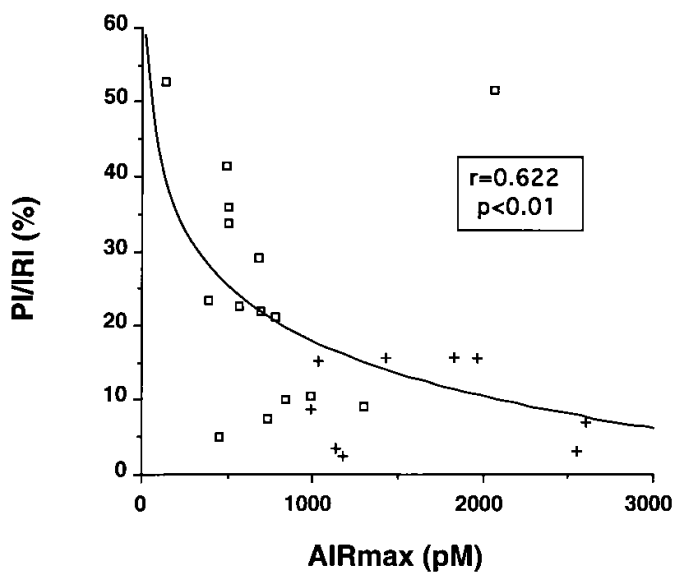

Figure 4. The ratio of total proinsulin to IRI correlates with $\mathrm{AIR}_{\max }$. The ratio of total proinsulin to IRI increased as a function of decreasing $\beta$ cell mass, as measured by $\operatorname{AIR}_{\text {max }}$ (see text) in donor ( $\square$ ) and control groups $(+)$.
Proinsulin measurements made by the two-site immunoradiometric assay yielded similar results to those made by the two-step assay using an antibody directed against C-peptide. Six donors were studied prospectively using this two-site assay, and intact proinsulin values were found to increase significantly after hemipancreatectomy (preoperative value: $3.2 \pm 1.6$ $\mathrm{pM}$ vs postoperative value of $9.4 \pm 3.7 \mathrm{pM}, P=0.025)$. 32,33 split proinsulin also increased after hemipancreatectomy in these donors $(10.0 \pm 6.8 \mathrm{pM}$ before surgery vs $45.4 \pm 21.7 \mathrm{pM}$ after surgery, $P=0.05)$. In addition, the proportion of IRI comprised of proinsulin and 32,33 proinsulin was higher after donation than before $(10.1 \pm 1.4 \%$ vs $37.2 \pm 10.8 \%, n=6, P=$ $0.05)$.

\section{Discussion}

In our investigation we found that total serum proinsulin, intact proinsulin, 32,33 split proinsulin, and the proportion of IRI comprised of proinsulin are all increased in human donors after hemipancreatectomy. These subjects, who were clinically healthy individuals with normal glucose tolerance and insulin secretory profiles before organ donation, demonstrated relative hyperglycemia and diminished maximal $\beta$ cell reserve capacity when compared with matched controls or their own predonation values. Since an increase in $\beta$ cell demand per cell would be expected to follow hemipancreatectomy, our data demonstrate that hyperproinsulinemia is associated with increased $\beta$ cell demand. These data are the first to document such an occurrence in hemipancreatectomized humans and may be important in understanding the pathophysiology of hyperproinsulinemia.

The mechanism responsible for relative hyperproinsulinemia to insulinemia has been the subject of much debate. Originally described in patients with type II diabetes mellitus (2224), relative hyperproinsulinemia has been proposed to arise as a result of an intrinsic $\beta$ cell defect in insulin processing present in this disease (9). Supporters of this hypothesis have suggested that individuals with disproportionate hyperproinsulinemia release greater than normal amounts of proinsulin from the $\beta$ cell because of an abnormality in posttranslational modification of the proinsulin molecule leading to a proinsulin-rich granule. In addition, they propose that hyperproinsulinemia may be a marker for later abnormalities in glucose tolerance. Supporting this theory are the findings of disproportionate levels of proinsulin in subjects believed to be at risk for the development of diabetes mellitus, such as women who have previously experienced gestational diabetes (3), firstdegree family members of individuals with type I diabetes mellitus (4-7), and subjects with impaired glucose tolerance who progress to type II diabetes (8).

Other investigators have suggested that disproportionate hyperproinsulinemia occurs as a result of increased demand on the $\beta$ cell and the subsequent release of immature insulinsecretory granules (10). Support for this hypothesis comes from investigations in animals with experimentally produced hyperglycemia $(10,25)$ and from human studies in which proinsulin concentrations were measured in first-degree relatives of patients with type II diabetes and found to be elevated only in those with hyperglycemia (26). Insulin resistance may also increase demand on $\beta$ cells, and absolute proinsulin concentrations have been demonstrated to increase in obesity (1). However, these elevations are proportional to an associated rise in 
insulin unless there is hyperglycemia. Some forms of druginduced insulin resistance also produce disproportionate hyperproinsulinemia in humans $(27)$; others do not $(28,29)$.

In our population, we found the absolute concentration of intact serum proinsulin, 32,33 split proinsulin, and the ratio of total proinsulin to IRI were increased in the donor groups compared with their preoperative control values or with measurements made in age and body mass index-matched controls. Since donors experience a decrease in $\mathrm{AIR}_{\max }$ and stimulated insulin secretion after hemipancreatectomy, our data support the hypothesis that hyperproinsulinemia may be the result of increased $\beta$ cell demand in these subjects. However, because our subjects are at increased genetic risk for the development of type I diabetes, it could also be suggested that hyperproinsulinemia is a marker for early dysfunction caused by the autoimmune destruction of $\beta$ cells. Detracting from such a conclusion is our finding of undetectable concentrations of islet cell antibodies in the serum of hemipancreatectomized donors at the time of study. These observations argue against isletitis as the cause of the $\beta$ cell dysfunction and hyperproinsulinemia found in the hemipancreatectomized donors. Furthermore, whereas $\mathrm{AIR}_{\max }$ was lower in the prospectively studied donor groups compared with the cross-sectional control group, the preoperative proinsulin measures were indistinguishable, suggesting that $\beta$ cell function was normal before hemipancreatectomy in these first-degree relatives of patients with type I diabetes. Therefore, our findings of relative hyperproinsulinemia in donors with normal preoperative $\beta$ cell function and an absence of immunologic evidence of isletitis postoperatively supports the hypothesis that hyperproinsulinemia developing after hemipancreatectomy is the result of reduced islet mass and the subsequent increase in $\beta$ cell demand.

It should be noted that previous investigators have found disproportionate hyperproinsulinemia in the first-degree relatives of patients with type I diabetes and have used these observations to suggest that this finding may be an early sign of $\beta$ cell dysfunction associated with type I diabetes (4-7). Whereas this conclusion may apply to the observations made in other groups of relatives of patients with type I diabetes, we do not believe it is relevant in our subjects, since they were selected based on variables that correlate with a lower risk for the development of type I diabetes (30) to insure that donors have normal pancreatic function before surgery. Consequently, they were older and more distant in age from the age of diabetes onset of the affected family member than were the family members included in other investigations of proinsulin in firstdegree relatives of patients with type I diabetes (4-7). However, even though our subjects were at a lower risk to develop diabetes than the subjects included in other studies and had normal preoperative $\beta$ cell function and no postoperative islet cell antibodies, one-third were found to have a diabetic response on an oral glucose tolerance test at the time of follow-up. Interestingly, most of these subjects with diabetic glucose tolerance have not developed fasting hyperglycemia, implying that their defect was mild. Thus, we conclude that absolute and relative hyperproinsulinemia developed after hemipancreatectomy as a result of the intervention in these subjects, which produced a reduction in maximal $\beta$ cell reserve capacity.

In this investigation, we demonstrate the presence of a significant positive relationship between PI/IRI and fasting glucose values, as has been previously been defined in humans (1, $2,31-33$ ) and rodents (10). Our data also define a significant relationship between PI/IRI and $\mathrm{AIR}_{\max }$, a measure of maximal pancreatic $\beta$ cell reserve capacity. We found that humans with the lowest $\mathrm{AIR}_{\max }$ values tended to have the greatest degree of disproportionate hyperproinsulinemia. These data differ from those obtained in two-thirds pancreatectomized dogs, in which no differences were found in the PI/IRI measured before and after surgical reduction of $\beta$ cell mass (29). It seems possible that dogs may have an adaptive response to such surgery. Alternatively, insufficient time may have elapsed after partial pancreatectomy and the development of reduced $\mathrm{AIR}_{\max }$ in the dogs for the effects of increased $\beta$ cell demand to be expressed as a change in PI/IRI. Ward et al. examined the dogs 1 and 6 wk after surgery (34), whereas the humans in the current investigation were studied no earlier than 12 mo and up to 96 mo after hemipancreatectomy. Regardless of these observations in canines, our data demonstrate that hyperproinsulinemia is significantly associated with fasting hyperglycemia and reduced maximal $\beta$ cell reserve capacity in hemipancreatectomized humans who served as donors to a family member with type I diabetes.

In conclusion, we have found that relative and absolute hyperproinsulinemia develops in clinically healthy human donors after hemipancreatectomy. Our observations support the hypothesis that disproportionate hyperproinsulinemia may result from increased $\beta$ cell demand in humans.

\section{Acknowledgments}

The authors gratefully acknowledge the expert care provided our subjects by the staff of the General Clinical Research Center at the University of Minnesota, the technical expertise of Laurie Pohlman, and the secretarial assistance of Jennifer Burkhart. Dr. Noel Maclaren generously measured islet cell antibody concentrations.

This work was supported in part by grants M01-RR00400, R01DK39994-05, DK-12829, and DK-17047 from the National Institutes of Health; the Department of Veteran's Affairs; the British Diabetic Association; and the Medical Research Council of Great Britain.

\section{References}

1. Shiraishi, I., Y. Iwamoto, T. Kuzuya, A. Matsuda, and S. Kumakura. 1991. Hyperinsulinaemia in obesity is not accompanied by an increase in serum proinsulin/insulin ratio in groups of human subjects with and without glucose intolerance. Diabetologia. 34:737-741.

2. Saad, M. F., S. E. Kahn, and R. G. Nelson. 1990. Disproportionately elevated proinsulin in Pima Indians with noninsulin-dependent diabetes mellitus. J. Clin. Endocrinol. \& Metab. 70:1247-1253.

3. Persson, B., U. Hanson, S. G. Hartling, and C. Binder. 1991. Follow-up of women with previous GDM. Insulin, C-peptide, and proinsulin responses to oral glucose load. Diabetes. 40(Suppl. 2):136-141.

4. Heaton, D. A., B. A. Millward, I. P. Gray, Y. Tun, C. N. Hales, D. A Pyke, and R. D. Leslie. 1988. Increased proinsulin levels as an early indicator of B-cell dysfunction in non-diabetic twins of type 1 (insulin-dependent) diabetic patients. Diabetologia. 31:182-184.

5. Hartling, S. G., F. Lindgren, G. Dahlqvist, and B. Persson. 1989. Elevated proinsulin in healthy siblings of IDDM patients independent of HLA identity. Diabetes. 38:1271-1274.

6. Lindgren, F. A., S. G. Hartling, G. G. Dahlquist, C. Binder, S. Efendic, and B. E. Persson. 1991. Glucose-induced insulin response is reduced and proinsulin response increased in healthy siblings of type 1 diabetic patients. Diabetic Med. 8:638-643.

7. Spinas, G. A., O. Snorgaard, S. G. Hartling, M. Oberholzer, and W. Berger. 1992. Elevated proinsulin levels related to islet cell antibodies in firstdegree relatives of IDDM patients. Diabetes Care. 15:632-637.

8. Kahn, S. E., D. L. Leonetti, R. L. Prigeon, E. J. Boyko, R. W. Bergstrom, and W. Y. Fujimoto. 1995. Proinsulin as a marker for the development of NIDDM in Japanese-American men. Diabetes. 44:173-179.

9. Porte, D., Jr., and S. E. Kahn. 1989. Hyperproinsulinemia and amyloid in NIDDM. Clues to etiology of islet $\beta$-cell dysfunction? Diabetes. 38:1333-1336.

10. Leahy, J. L., P. A. Halban, and G. C. Weir. 1991. Relative hypersecre- 
tion of proinsulin in rat model of NIDDM. Diabetes. 40:885-889.

11. Seaquist, E. R., and R. P. Robertson. 1992. Effects of hemipancreatectomy on pancreatic $\alpha$ and $\beta$ cell function in healthy human donors. J. Clin. Invest. 89:1761-1766.

12. Sutherland, D. E. 1987. Pancreas transplantation. Diabetes Metab. Rev. 3:1061-1090.

13. Kendall, D. M., D. E. R. Sutherland, J. S. Najarian, F. C. Goetz, and R. P. Robertson. 1990. Effects of hemipancreatectomy on insulin secretion and glucose tolerance in healthy humans. N. Engl. J. Med. 322:898-903.

14. Seaquist, E. R., K. Pyzdrowski, A. Moran, A. U. Teuscher, and R. P. Robertson. 1994. Insulin-mediated and glucose-mediated glucose uptake following hemipancreatectomy in healthy human donors. Diabetologia. 37:10361043 .

15. Halter, J. B., R. J. Graf, and D. Porte, Jr. 1979. Potentiation of insulin secretory responses by plasma glucose levels in man: evidence that hyperglycemia in diabetes compensates for impaired glucose potentiation. J. Clin. Endocrinol. \& Metab. 48:946-954.

16. Ward, W. K., D. C. Bolgiano, B. McKnight, J. B. Halter, and D. Porte, Jr. 1984. Diminished B cell secretory capacity in patients with non-insulindependent diabetes mellitus. J. Clin. Invest. 74:1318-1328.

17. Morgan, C. R., and A. Lazarow. 1963. Immunoassay of insulin: two antibody system. Plasma insulin levels of normal, subdiabetic and diabetic rats. $\mathrm{Di}$ abetes. 12:115-126

18. Ward, W. K., T. L. Paquette, B. H. Frank, and D. Porte, Jr. 1986. A sensitive radioimmunoassay for human proinsulin, with sequential use of antisera to C-peptide and insulin. Clin. Chem. 32:728-733.

19. Rhodes, C. J., and C. Alarcón. 1994. What $\beta$-cell defect could lead to hyperproinsulinemia in NIDDM? Diabetes. 43:511-517.

20. Sobey, W. J., S. F. Beer, C. A. Carrington, P. M. Clark, B. H. Frank, I. P. Gray, S. D. Luzio, D. R. Owens, A. E. Schneider, K. Siddle, et al. 1989. Sensitive and specific two-site immunoradiometric assays for human insulin, proinsulin, 65-66 split and 32-33 split proinsulins. Biochem. J. 260:535-541.

21. Neufeld, M., N. K. Maclaren, W. J. Riley, D. Lezottes, J. V. McLaughlin, J. Silverstein, and A. L. Rosenbloom. 1980. Islet cell and other organ-specific antibodies in U.S. Caucasians and Blacks with insulin-dependent diabetes mellitus. Diabetes. 29:589-592.

22. Duckworth, W. C., A. E. Kitabchi, and M. Heinemann. 1972. Direct measurement of plasma proinsulin in normal and diabetic subjects. Am. J. Med. $53: 418-427$.
23. Gorden, P., C. M. Hendricks, and J. Roth. 1974. Circulating proinsulinlike component in man: increased proportion in hypoinsulinemic states. Diabetologia. 10:469-474.

24. Ward, W. K., E. C. LaCava, T. L. Paquette, J. C. Beard, B. J. Wallum, and D. Porte, Jr. 1987. Disproportionate elevation of immunoreactive proinsulin in type 2 (non-insulin-dependent) diabetes mellitus and in experimental insulin resistance. Diabetologia. 30:698-702.

25. Alarcón, C., J. L. Leahy, G. T. Schuppin, and C. J. Rhodes. 1995. Increased secretory demand rather than a defect in the proinsulin conversion mechanism causes hyperproinsulinemia in a glucose-infusion rat model of noninsulin-dependent diabetes mellitus. J. Clin. Invest. 95:1032-1039.

26. Birkeland, K. I., P. A. Torjesen, and J. Eriksson. 1994. Hyperproinsulinemia of type II diabetes is not present before the development of hyperglycemia. Diabetes Care. 17:1307-1310.

27. Kahn, S. E., F. F. Horber, R. L. Prigeon, and M. W. Haymond. 1993. Effect of glucocorticoid and growth hormone treatment on proinsulin levels in humans. Diabetes. 42:1082-1085.

28. Kahn, S. E., J. C. Beard, M. W. Schwartz, W. K. Ward, H. L. Ding, R. N. Bergman, G. J. Taborsky, Jr., and D. Porte, Jr. 1989. Increased $\beta$-cell secretory capacity as mechanism for islet adaptation to nicotinic acid-induced insulin resistance. Diabetes. 38:562-568.

29. Porte, D., Jr. 1991. $\beta$-cells in type II diabetes mellitus. Diabetes. 40:166180

30. Barbosa, J., R. King, and H. Noreen. 1977. The histocompatibility system in juvenile, insulin-dependent diabetic multiplex kindreds. J. Clin. Invest 60:989-998.

31. Beer, S. F., S. O'Rahilly, R. S. Spivey, C. N. Hales, and R. C. Turner. 1990. Plasma proinsulin in first-degree relatives of type 2 diabetic subjects. Diabetes Res. 14:51-54.

32. Williams, D. R. R., C. Byrne, P. M. S. Clark, L. Cox, N. E. Day, G. Rayman, and T. Wang. 1991. Raised proinsulin concentration as early indicator of $\beta$ cell dysfunction. Br. Med. J. 303:95-96.

33. Haffner, S. M., R. R. Bowsher, L. Mykkanen, H. P. Hazuda, B. D. Mitchell, R. A. Valdez, R. Gingerich, A. Monterossa, and M. P. Stern. 1994 Proinsulin and specific insulin concentration in high- and low-risk populations for NIDDM. Diabetes. 43:1490-1493.

34. Ward, W. K., B. J. Wallum, J. C. Beard, G. J. Taborsky, Jr., and D. Porte, Jr. 1988. Reduction of glycemic potentiation. Sensitive indicator of $\beta$-cell loss in partially pancreatectomized dogs. Diabetes. 37:723-729. 